Note

\section{Characteristics of Acid Urease from Streptococcus mitior}

\author{
Eiichirou Yamazaki, Takashi Kurasawa, \\ Shigeya Kakimoto, * Yasuhiro Sumino* \\ and Isamu NAKATSUI \\ Food Research Laboratories, Food Products Division, \\ Takeda Chemical Industries, Ltd., \\ I-5, Aioi-machi, Takasago-cho, \\ Takasago 676, Japan \\ * Microbiology Research Laboratories, \\ Research and Development Division, \\ Takeda Chemical Industries, Ltd. \\ 17-85, Juso-honmachi 2-chome, \\ Yodogawa-ku, Osaka 532, Japan \\ Received February 1, 1990
}

Ethylcarbamate, which is known to be carcinogenic, is thought to be formed from urea and ethyl alcohol in alcoholic beverages. ${ }^{1)}$ Acid urease is effective in preventing the formation of ethylcarbamate, but only the enzyme from Lactobacillus fermentum has previously been partially purified and characterized. ${ }^{2)}$ We started our research by examining the distribution of acid urease-producing microorganisms and isolated 700 producers. These isolates belonged to 6 genera, strains of the genera Streptococcus and Lactobacillus being dominant. ${ }^{37}$ The acid ureases from 37 representative isolates from these 700 producers were classified into 6 different types of the enzyme according to their electrophoretic mobility. ${ }^{4)}$ Two different types of acid urease, one from $L$. reuter ${ }^{5)}$ and one from $L$. fermentum, ${ }^{6}$ ) have been highly purified and characterized, but little is known of the properties of the acid ureases produced by Streptococcus strains. This report describes the purification and characterization of the acid urease from a new isolate of $S$. mitior. This acid urease differs from the Lactobacillus acid ureases in electrophoretic mobility and molecular weight of the subunits.

S. mitior PG-118, which was isolated from rat feces, ${ }^{3)}$ was statically grown at $37^{\circ} \mathrm{C}$ for $48 \mathrm{hr}$ in a medium containing $3.0 \%$ glucose (separately sterilized), $0.2 \%$ sodium acetate, $1.5 \%$ Polypepton (Nihon Seiyaku, Tokyo), $1.0 \%$ meat extract, $0.8 \%$ yeast extract, $0.5 \% \mathrm{NaCl}, 0.5 \%$ urea, $0.005 \% \quad \mathrm{MnSO}_{4} \cdot 4-6 \mathrm{H}_{2} \mathrm{O}$, and $0.005 \% \mathrm{NiSO}_{4} \cdot 6$ $\mathrm{H}_{2} \mathrm{O}$. Cells were harvested by centrifugation, washed twice with $10 \mathrm{~mm}$ tris(hydroxymethyl)aminomethane (Tris)-hydrochloride buffer ( $\mathrm{pH} 7.0$ ), and then stored at $-80^{\circ} \mathrm{C}$ until use.

Acid urease activity was assayed at $37^{\circ} \mathrm{C}$ by measuring the rate of release of ammonia from urea. The standard reaction mixture contained $167 \mathrm{mM}$ urea and $0.2 \mathrm{M}$ citrate buffer ( $\mathrm{pH} \mathrm{4.0)}$. The reaction was started by adding $2 \mathrm{ml}$ of an enzyme solution to $2 \mathrm{ml}$ of the standard reaction mixture. The reaction was stopped by adding $4 \mathrm{ml}$ of $10 \%$ trichloroacetic acid. After the precipitate had been removed by centrifugation, the amount of ammonia in the supernatant was measured spectrophotometrically at $625 \mathrm{~nm}$ by the method of Weatherburn. ${ }^{7)}$ One unit of enzyme activity was defined as the amount of enzyme required for the formation of $1 \mu \mathrm{mol}$ of ammonia from urea per min under the standard conditions.

Ethylcarbamate was extracted from sake by the method of Joe et al. ${ }^{8)}$ Ethylcarbamate was measured with a GC-9A gas chromatography system (Shimazu Corporation, Tokyo) on a Chromosorb W (AW) column $(0.3 \times 200 \mathrm{~cm}$; Gasukuro Kogyo, Inc., Tokyo) coated with $10 \%$ ethylene glycol adipate.

Other materials and methods were the same as those described in our previous paper. ${ }^{5)}$

The acid urease from $S$. mitior was purified about 27 -fold, with a recovery of $14.9 \%$ (Table $I$ ), by a multi-step procedure involving ethanol extraction, Toyopearl HW-55, DEAE-Sepharose CL-6B and affinity gel column chromatographic fractionations, and isoelectric focusing as described previously. ${ }^{5)}$ As shown in Fig. 1A, poly-

Table I. Purification of ACID UREase From $S$. mitior

\begin{tabular}{lccccc}
\hline Step & $\begin{array}{c}\text { Total } \\
\text { protein } \\
(\mathrm{mg})\end{array}$ & $\begin{array}{c}\text { Total } \\
\text { activity } \\
\text { (units) }\end{array}$ & $\begin{array}{c}\text { Specific } \\
\text { activity } \\
\text { (units/mg) }\end{array}$ & $\begin{array}{c}\text { Purification } \\
\text { (-fold) }\end{array}$ & $\begin{array}{c}\text { Yield } \\
(\%)\end{array}$ \\
\hline Extraction & 1150 & 19,500 & 16.9 & 1.0 & 100 \\
Ethanol precipitation & 436 & 17,700 & 40.6 & 2.4 & 90.8 \\
Toyopearl HW-55F & 105 & 11,900 & 113 & 6.7 & 61.0 \\
DEAE-Sepharose CL-6B & 56.0 & 9,850 & 176 & 10.4 & 50.5 \\
First affinity gel & 11.7 & 5.480 & 469 & 27.8 & 28.1 \\
Chromatofocusing & $\mathrm{NT}^{a}$ & 3,490 & $\mathrm{NT}$ & $\mathrm{NT}$ & 17.9 \\
Second affinity gel & 6.3 & 2,900 & 458 & 27.1 & 14.9 \\
\hline
\end{tabular}

a NT, not tested. 

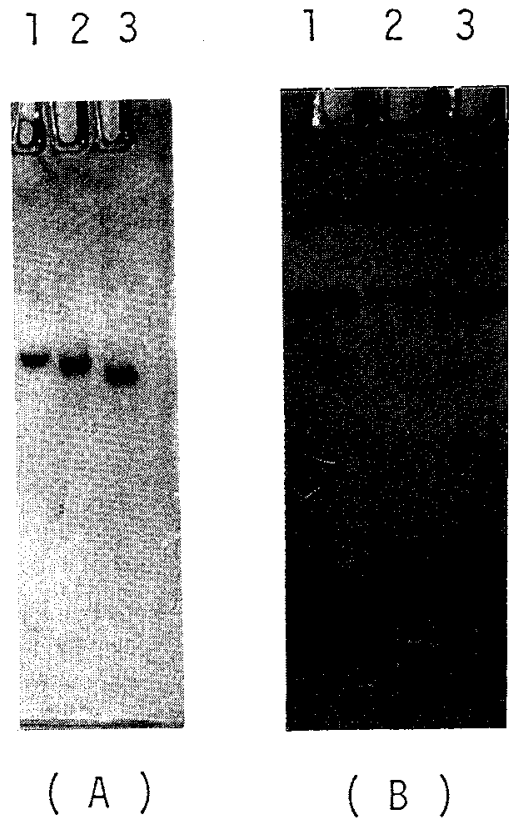

Fig. 1. Polyacrylamide Gel Electrophoresis of Acid Urease from $S$. mitior.

(A) $6 \mu \mathrm{g}$ of each of the purified enzymes was electrophoresed on a $6 \%$ polyacrylamide gel. (B) $3 \mu \mathrm{g}$ of each of the purified enzymes was electrophoresed on a $15 \%$ SDS-polyacrylamide gel. Lanes: $1, L$. fermentum IFO $14511^{6)} ; 2$, L. reuteri Rt-5 ${ }^{5)}$ 3, S. mitior PG-1 18.

acrylamide gel electrophoresis of the purified acid urease from $S$. mitior gave a single band. The mobility of the acid urease from $S$. mitior was different from that of $L$. reuteri ${ }^{5 \text { ) }}$ and from that of L. fermentum. ${ }^{6}$

The molecular weight of the acid urease from $S$. mitior was about 200,000 by Sepharose CL-6B gel filtration. $S$. mitior acid urease was found to contain 3 kinds of subunits on sodium dodecyl sulfate (SDS)-polyacrylamide gel electrophoresis (PAGE), as shown in Fig. 1B. The molecular weights of the 3 subunits, $\alpha, \beta$, and $\gamma$, of the acid urease from $S$. mitior were $66,000,15,600$, and 8,600 , respectively, using a $15 \%$ acrylamide gel. The mobilities of the subunits of the acid urease from $S$. mitior were different from those of the acid urease from $L$. reuteri and from L. fermentum (Fig. 1B). The molecular weights of the 3 subunits, $\alpha, \beta$, and $\gamma$, of the urease from $L$. reuter $i^{5}$ ) were $68,000,16,100$, and 8,800 , respectively, and those of that from L. fermentum ${ }^{6)}$ were $67,000,16,800$, and 8,600, respectively. The approximate subunit ratio of the acid urease from $S$. mitior was $1: 2: 1$, which was calculated from the integrated intensities of the gel scan profile and from calculations based on the molecular weight of 200,000 obtained on gel filtration chromatography and the molecular weights of the 3 subunits estimated by SDS-PAGE. The isoelectric point of $S$. mitior acid urease
Table II. Amino ACid COMPosition of ACID UREASE FROM $S$. mitior ${ }^{a}$

\begin{tabular}{lrr}
\hline Amino acid & $\begin{array}{c}\text { Residues }^{b} \text { per } \\
\text { molecule }\end{array}$ & $\begin{array}{c}\text { Mole percent } \\
(\%)\end{array}$ \\
\hline Asp $^{c}$ & 222.7 & 12.1 \\
Thr $^{d}$ & 137.3 & 7.4 \\
Ser $^{d}$ & 98.6 & 5.4 \\
Glu $^{c}$ & 156.8 & 8.5 \\
Pro & 76.9 & 4.2 \\
Gly & 187.8 & 10.2 \\
Ala & 150.8 & 8.2 \\
H-cys & 23.0 & 1.2 \\
Val & 139.2 & 7.5 \\
Met & 63.4 & 3.4 \\
Ile & 112.1 & 6.1 \\
Leu & 114.9 & 6.2 \\
Tyr & 77.4 & 4.2 \\
Phe & 44.5 & 2.4 \\
His & 46.6 & 2.5 \\
Lys & 114.7 & 6.2 \\
Arg & 72.8 & 4.0 \\
Trp & 6.0 & 0.3 \\
& &
\end{tabular}

a The values are the averages for 24-, 48- and 72-hr hydrolyses in $6 \mathrm{~N} \mathrm{HCl}$ containing $4 \%(\mathrm{v} / \mathrm{v})$ thioglycolic acid at $110^{\circ} \mathrm{C}$.

$b$ Calculations were based on a molecular weight of 200,000.

c Free amino acid and corresponding amide.

d Obtained by extrapolation to zero time of hydrolysis.

e H-cys: Half-cystine measured as cysteic acid in a $24-\mathrm{hr}$ hydrolysate after performic acid oxidation.

was $\mathrm{pH} 4.6$ by isoelectric focusing.

The $S$. mitior acid urease also contained nickel, and the content was calculated to be $1.9 \mathrm{~mol}$ of nickel per mol of the $\alpha_{1} \beta_{2} \gamma_{1}$ structural unit. This indicates that this acid urease contained $2 \mathrm{~mol}$ of nickel per mol of the $\alpha_{1} \beta_{2} \gamma_{1}$ structural unit.

The amino acid composition of the acid urease from $S$. mitior is shown in Table II. This amino acid composition resembles those of the acid ureases from $L$. reuteri ${ }^{5)}$ and L. fermentum. ) $^{\text {) }}$

The optimum $\mathrm{pH}$ for the acid urease from $S$. mitior was around $\mathrm{pH} 4.5$. The enzyme activity was maximum at 60 to $70^{\circ} \mathrm{C}$, and was stable from pH 4 to 8 at $37^{\circ} \mathrm{C}$ for $30 \mathrm{~min}$. When incubated for $30 \mathrm{~min}$ at $\mathrm{pH} 4$, the enzyme activity was stable below $40^{\circ} \mathrm{C}$.

The effects of metal ions $(5.0 \mathrm{~mm})$ on the enzyme activity of the acid urease from $S$. mitior were examined by adding metal ions, $\mathrm{Mg}^{2+}, \mathrm{Ca}^{2+}, \mathrm{Mn}^{2+}, \mathrm{Fe}^{2+}, \mathrm{Co}^{2+}, \mathrm{Ni}^{2+}, \mathrm{Cu}^{2+}$, $\mathrm{Zn}^{2+}, \mathrm{Sr}^{2+}, \mathrm{Ag}^{+}, \mathrm{Sn}^{2+}, \mathrm{Ba}^{2+}$, and $\mathrm{Hg}^{2+}$, to the standard reaction mixture. The activity was completely inhibited by $\mathrm{Hg}^{2+}$ and $\mathrm{Ag}^{+}$and was reduced to $27 \%$ in the presence of $\mathrm{Cu}^{2+}$. The enzyme activity was strongly inhibited by sulfhydryl reagents such as $p$-chloromercuribenzoic acid 
Table III. Prevention of Ethylcarbamate FORMATION IN SAKE ${ }^{a}$

\begin{tabular}{cccccc}
\hline & & \multicolumn{4}{c}{ Ethylcarbamate (ppb) } \\
\cline { 3 - 6 } $\begin{array}{c}\text { Urea } \\
(\mathrm{ppm})\end{array}$ & $\begin{array}{c}\text { Temperature } \\
\left({ }^{\circ} \mathrm{C}\right)\end{array}$ & \multicolumn{3}{c}{ Incubation time (months) } \\
\cline { 3 - 7 } & & 0 & 1 & 2 & 3 \\
\hline \multirow{2}{*}{$0^{b}$} & 10 & $\mathrm{ND}^{c}$ & $\mathrm{ND}$ & $\mathrm{ND}$ & $\mathrm{ND}$ \\
& 30 & $\mathrm{ND}$ & $\mathrm{ND}$ & $\mathrm{ND}$ & $\mathrm{ND}$ \\
30 & 10 & $\mathrm{ND}$ & $\mathrm{ND}$ & $\mathrm{ND}$ & $\mathrm{ND}$ \\
& 30 & ND & 40 & 60 & 110
\end{tabular}

a $\mathrm{pH}$ of the sake was 4.4 and the ethyl alcohol content was $19 \%$.

b Urea was eliminated by the action of 100 units $/ \mathrm{ml}$ of S. mitior acid urease.

c ND, not detected.

and by chelating reagents such as acetohydroxamic acid.

The acid urease was active against urea, but not against thiourea, methylurea, or ethylurea. This substrate specificity profile is very similar to those of the ureases from jack bean, ${ }^{9)} L$. reuteri, ${ }^{5)}$ and $L$. fermentum. ${ }^{6)}$ The rate of hydrolysis of urea by the acid urease from S. mitior was measured at $37^{\circ} \mathrm{C}$ in $0.1 \mathrm{M}$ citrate buffer, $\mathrm{pH} 4.5$. Plots of the reaction velocity against urea concentration gave a normal Michaelis-Menten curve. The $\mathrm{Km}$ for urea was $2.0 \mathrm{~mm}$ and the $V_{\max }$ was 460 units/mg.

The effect of temperature on the elimination of the urea in sake was examined using purified S. mitior acid urease. The urea was eliminated faster with increasing temperature up to $35^{\circ} \mathrm{C}$, but the urea was not eliminated at $40^{\circ} \mathrm{C}$. The acid urease seems to be inactivated in sake at this temperature. The urea in sake was completely eliminated at $35^{\circ} \mathrm{C}$ in 4 days.

We examined the formation of ethylcarbamate using urea-free and urea-containing sake (Table III). When ethylcarbamate-free sake, which contained $30 \mathrm{ppm}$ urea, was incubated at $30^{\circ} \mathrm{C}$ for 3 months, $110 \mathrm{ppb}$ ethylcarbamate was formed. But, when the sake from which urea had been eliminated almost completely by the action of $S$. mitior acid urease was incubated at $30^{\circ} \mathrm{C}$ for 3 months, no ethylcarbamate was formed.

\section{References}

1) S. Hara, K. Yoshizawa and K. Nakamura, J. Brew. Soc. Jpn., 83, 57 (1988).

2) S. Takebe and K. Kobashi, Chem. Pharm. Bull., 36, 693 (1988).

3) S. Kakimoto, K. Okazaki, Y. Sakane, K. Imai, Y. Sumino, S. Akiyama and Y. Nakao, Agric. Biol. Chem., 53, 1111 (1989).

4) S. Kakimoto, H. Miyashita, Y. Sumino and S. Akiyama, Agric. Biol. Chem., 54, 381 (1990).

5) S. Kakimoto, Y. Sumino, S. Akiyama and Y. Nakao, Agric. Biol. Chem., 53, 1119 (1989).

6) S. Kakimoto, Y. Sumino, K. Kawahara, E. Yamazaki and I. Nakatsui, Appl. Microbiol. Biotechnol., 32, 538 (1990).

7) M. M. Weatherburn, Anal. Chem., 39, 971 (1967).

8) F. L. Joe, Jr., D. A. Kline, E. M. Miletta, J. A. G. Roach, E. L. Roseboro and T. Fazio, J. Assoc. Off. Anal. Chem., 60, 509 (1977).

9) M. Dixon and E. C. Webb, "Enzymes," 3rd Ed., Longman Group Ltd., London, 1979, p. 263. 